\title{
Vendian stratigraphy and sedimentology of the East Greenland Caledonides
}

\author{
M. J. Hambrey and A. C. M. Moncrieff
}

The present two-year programme 1984-1985 on the Vendian Tillite Group in central East Greenland follows comprehensive investigations on similar sequences in eastern Svalbard. The project aims to establish through Vendian time the disposition of land masses and oceans in relation to the East Greenland depositional environment, and to erect detailed stratigraphic correlations with other parts of the North Atlantic - Arctic region. This is important for understanding the tectonic evolution of the region prior to the opening of the Iapetus Ocean.

The work is a collaborative venture involving N. Abrahamsen (University of Aarhus, palaeomagnetism), G. Bylund (University of Lund, palaeomagnetism), A. H. Knoll (Harvard University, biostratigraphy), A. M. Spencer (Statoil, sedimentology), K. Swett (University of Iowa, sedimentology of bounding rock units) and G. Vidal (University of Lund, biostratigraphy). The authors were accompanied in the 1984 field season by Bylund and Vidal who undertook extensive sampling of the Late Proterozoic to Early Palaeozoic sequence.

\section{Objectives}

It has been known for some years that it is possible to make reasonable correlations between Late Precambrian sequences in East Greenland and eastern Svalbard. These sequences are remarkably similar, suggesting that the two areas were juxtaposed in Late Precambrian time (e.g. Harland, 1964; Hambrey, 1983). Furthermore the western Svalbard succession, though of the same age and also containing glacigenic rocks, is very different in appearance from that in East Greenland and eastern Svalbard. Major strike-slip motions are proposed for Palaeozoic time; the evidence for this is accumulating from several parts of the Caledonian orogen.

The sedimentology, lithostratigraphy and geochemistry of the Vendian rocks of East Greenland, especially the tillites, will be compared with those of eastern Svalbard. It is expected that constraints will be placed on the configuration of land and sea for that period, and on the timing of the opening of the Iapetus Ocean. Confirmation that East Greenland and eastern Svalbard were juxtaposed will preclude the possibility that an ocean existed between the two areas for much of Vendian time. With a source area for the Vendian ice sheet recently established as lying to the south-east the time is now opportune to test the hypothesis that the material comprising the East Greenland tillites was derived from the same area. Palaeocurrent analysis of the overlying and underlying rocks will place the sedimentation of the tillites in a broader time framework for the evolution of the Caledonian geosyncline.

The collaborative work is expected to provide a biostratigeographic and geochronometric time-scale, while palaeomagnetic studies should provide data on the relative late Precambrian-Palaeozoic polar wandering paths for disparate fragments of the Caledonides.

An additional outcome of the project will be the compilation of data concerning the local 
palaeogeographical environment during the two main glacial epochs of the Varangian glacial period. As with eastern Svalbard, it is expected that marine-intertidal-terrestrial glacial environments will be recognised in the Tillite Group. Together, the two areas will enable us to establish a depositional model for comparison with theoretical models and studies of the contemporary environment around Antarctica.

\section{Stratigraphy and geographical distribution of the Tillite Group}

The Vendian Tillite Group occurs in the upper part of the $17 \mathrm{~km}$ thick Late Proterozoic Early Palaeozoic sedimentary succession. It is overlain by Cambro-Ordovician rocks which largely consist of carbonates, and is underlain by the Eleonore Bay Group with carbonates forming the bulk of the immediately underlying formation, the Limestone-Dolomite 'series' (Henriksen \& Higgins, 1976). Shallow shelf and tidal conditions are represented throughout the whole succession, though conditions when the Tillite Group itself was deposited were rather complex, and sometimes subaerial (Spencer, in press).

The Tillite Group comprises five formations, namely:

Spiral Creek Formation - carbonates, sandstones

Canyon Formation - dolomitic shales

Upper Tillite - diamictites, sandstones, conglomerates

Inter-Tillite Beds - sandstones and shales

Lower Tillite - diamictites, sandstones, conglomerates

It will be observed in the discussion that the use of a genetic term like 'tillite' in formal stratigraphic nomenclature is misleading, and in due course we hope to rectify this. The group is variable in thickness, reaching $1300 \mathrm{~m}$ in some places. Biostratigraphic work by Vidal (1979a) using acritarchs has established a Vendian age for the Tillite Group and a Late Riphean one for the underlying rocks.

The Tillite Group is best exposed in the Kejser Franz Joseph Fjord and Kong Oscar Fjord region, but it also occurs in Ole Rømer Land and Hudson Land in the north, and Canning Land in the south (fig. 32). Despite considerable work in the area and publication of several detailed stratigraphic sections, as well as frequent reference to sedimentary structures (reviewed by Higgins, 1981), little is known of the precise mode of deposition of the alleged glacigenic and associated strata. Both glaciomarine and terrestrial glacial deposition have been suggested; indeed some have argued that the rocks are not glacial at all. However, the evidence previously presented (summarised by Higgins 1981) is strongly in favour of a glacial origin. This is supported by the work of Spencer who undertook detailed sedimentary logging at several localities (Spencer, in press). Spencer's conclusions were that although glacio-marine depostion did occur, for much of the time deposition occurred from grounded ice, and that periglacial activity was widespread.

The authors revisited several of Spencer's localities, namely Ella $\varnothing$, Arenaen in western Ymer $\emptyset$, Kap Lagerberg and north Syltoppene. Visits were made also to northern Suess Land, south-west Ymer $\emptyset$ adjacent to Antarctic Sund, and Canning Land. Other localities in the fjord region will be visited in 1985 .

Diamictites in each of the two tillite levels are of contrasting appearance and composition. The upper one contains a high proportion of igneous and metamorphic material, especially 


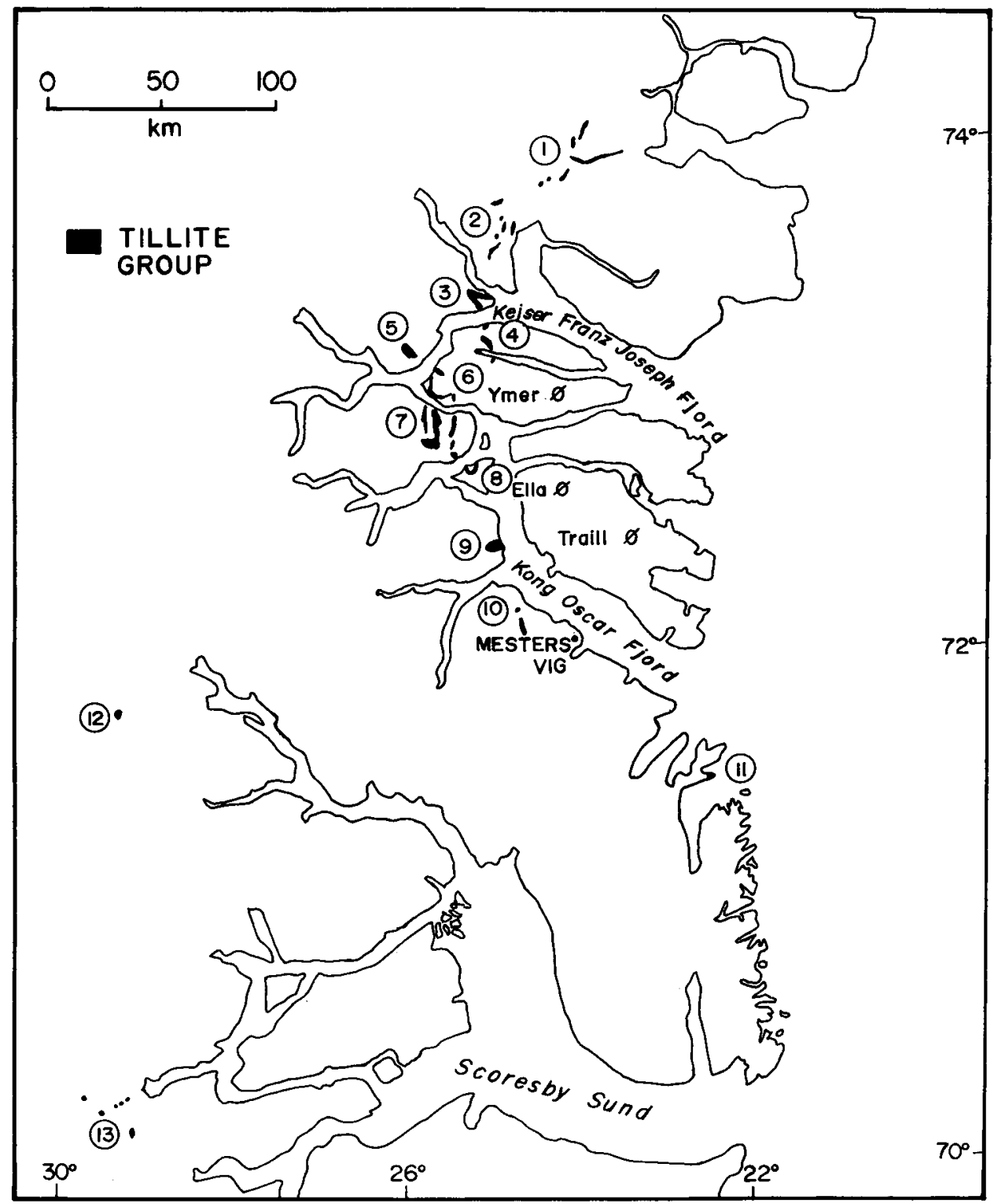

Fig. 32. Distribution of outcrops of the Tillite Group, central East Greenland. Localities referred to in text:

1. Ole Rømer Land \& Hudson Land

2. Waltershausen Gletscher

3. Kap Weber, E. Andrée Land

4. Arenaen, Gunnar Andersson Land

5. Junction Dal, S. Andrée Land

6. S. W. Ymer $\emptyset$

7. N. Suess Land
8. Kap Oswald, Ella $\varnothing$

9. Kap Lagerberg, Lyell Land

10. N. Syltoppene, N. Scoresby Land

11. Kap Fletcher, Canning Land

12. Tillit Nunatak, Charcot Land

13. Vestfjord Gletscher, W. Gåseland \& Paul Stern Land 
red granites and gneisses, the source area of which is at present unknown. Sedimentary clasts derived from the Limestone-Dolomite 'series' are also present. Frequently the diamitite is maroon in colour (possibly due to diagenesis), a characteristic of many Late Proterozoic tillites. The Lower Tillite is highly calcareous or dolomitic and contains only clasts from the Limestone-Dolomite 'series', except at its top where a handful of gneiss and granite clasts have been found. The general appearance is yellowish grey except at north Syltoppene and Kap Lagerberg where local reddening may be associated with Tertiary or Caledonian igneous activity. Both Upper and Lower tillites vary considerably in thickness from a few metres to well over $100 \mathrm{~m}$. Facies changes are rapid, particularly in the Upper Tillite, and individual members can rarely be traced for more than a few kilometres.

Tillites also occur in windows in the metamorphic complexes to the south-west; they are currently correlated with the succession in the fjord region. The principal localities are in western Gåseland and Paul Stern Land (Phillips \& Friderichsen, 1981) and at Tillit Nunatak in Charcot Land (Henriksen, 1981). In these areas the tillites rest on metamorphic or igneous rocks, rather than on sediments typical of the Eleonore Bay Group.

\section{Description of localities (from north to south)}

In this summary the localities visited in 1984 are described. One measured section is illustrated. In view of the wide range of facies represented at each locality, these are discussed altogether in the following section.

Arenaen, west Ymer $\emptyset$. Well exposed sections occur on the mountain-side known as Arenaen in the south of Gunnar Andersson Land. The Tillite Group is essentially complete in this locality, although faulting has disrupted the succession to some extent. The Lower Tillite is only a few metres thick and rests on dark grey shaly limestones. The Upper Tillite is about $200 \mathrm{~m}$ thick but, in addition to diamictite, contains a high proportion of sandstone and conglomerate in lens-shaped bodies, especially towards the top. These bodies indicate the action of powerful streams or currents towards the end of the glacial epoch. The formation is capped by about $8 \mathrm{~m}$ of distinctive yellow weathering, detrital dolostone, a feature absent to the south, but characteristic of all the north-east Svalbard successions.

Antarctic Sund, south-west Ymer $\emptyset$. A gully with a waterfall revealed a section from the top of the Limestone-Dolomite 'series', through a substantial thickness of Lower Tillite and Inter Tillite sandstones and shales, into cliff-forming Upper Tillite. The latter in fact contains very little diamictite, the bulk being sandstone. Although flat-lying, the rocks here are tectonised with a pronounced cleavage and mild metamorphism; thrusting is also in evidence.

Antarctic Sund, north Suess Land. Opposite the Ymer $\emptyset$ locality a continuous section from the Upper Limestone-Dolomite 'series' into the base of the Canyon Formation is present, notably in the north and west faces of Trugbjerg. The upper part of the Limestone-Dolomite 'series' contains a number of diamictite units with a suggestion that ice-rafted debris was incorporated prior to slumping. The base of the Lower Tillite is marked by a concentration of large clasts, mainly of dolomite, which appear to be dropstones. The contact is sharp but conformable at this locality. The Lower Tillite, perhaps $100 \mathrm{~m}$ thick or more, is succeeded by predominantly dolomitic slates with thin more sandy beds. The Upper Tillite is not well exposed on the west flank of Trugbjerg (it is probably better exposed in the rather inaccessible cliffs above Langgletscher). To the north of Antarctic Sund, the bulk of the Upper Tillite is sandstone. The Canyon Formation, which forms the summit of Trugbjerg, comprises flaggy dolostones and shales. The rocks are tectonised in a similar manner to those across the sound.

Ella $\emptyset$. The Kap Oswald area of Ella $\emptyset$ is one of the classic areas for the study of Vendian stratigraphy in East Greenland, there being a complete succession of pre-tillite to Cambro-Ordovician strata 


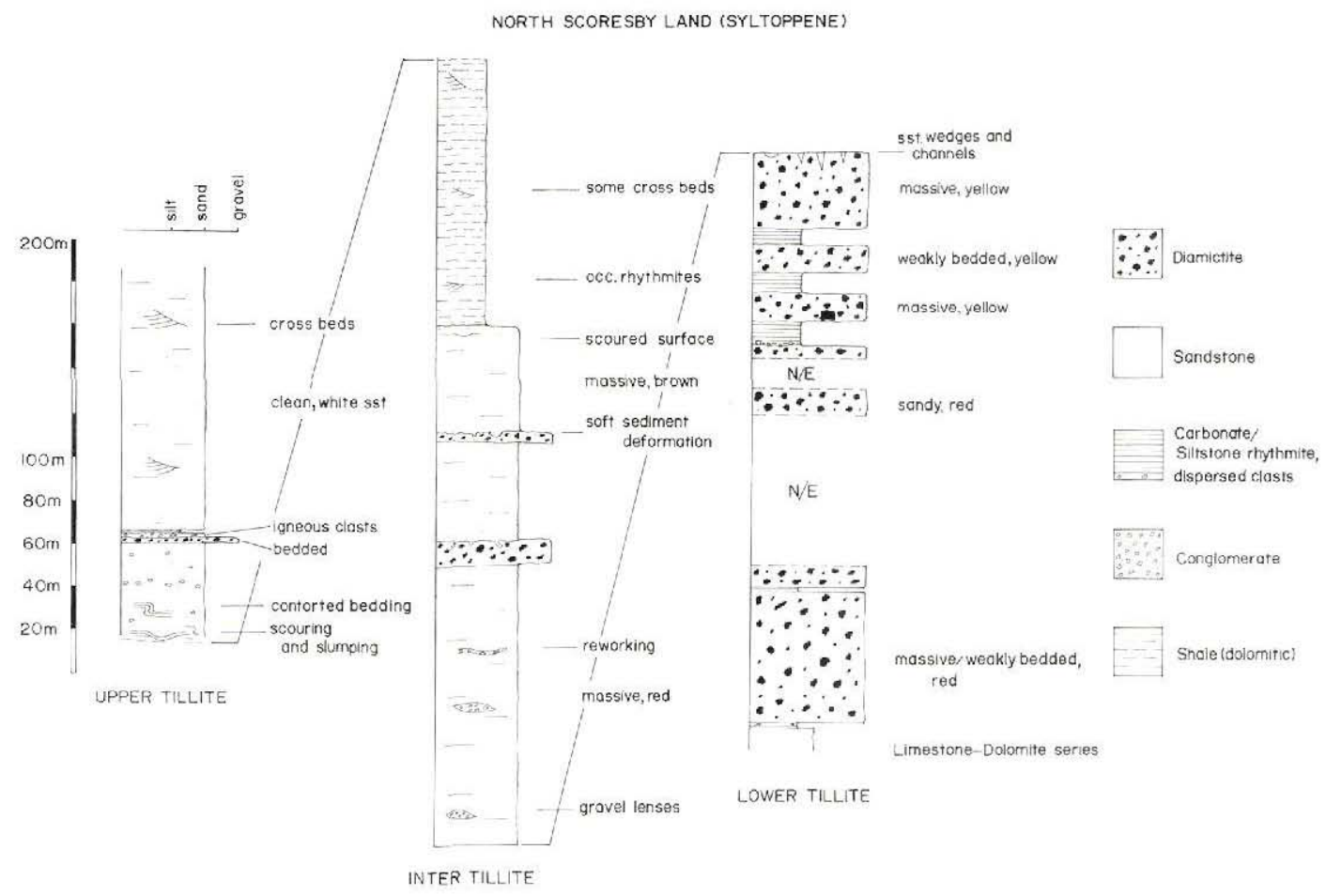

Fig. 33. Simplified measured section through the Tillite Group on the lower slopes of northern Syltoppene, north Scoresby Land.

exposed in Storeelv, around the coast of Tømmerbugt and Bastionbugt, and in Kløftelv. Spencer (in press) presented a summary of the succession in this area. The Lower Tillite is $c .120 \mathrm{~m}$ thick in places, the Upper Tillite over $200 \mathrm{~m}$, and the whole Tillite Group about $700 \mathrm{~m}$.

Kap Lagerberg. A gully leading into the stream that debouches just south of Kap Lagerberg provides an excellent section through the upper Limestone-Dolomite 'series' $(100 \mathrm{~m})$ and Lower Tillite $(c .90 \mathrm{~m})$, while the nearby eastern slopes of point 800 give a poor section through the Upper Tillite, there being almost no Inter-Tillite Beds exposed. Although little deformed, the rocks in places are strongly reddened and calcite-veined along joints and bedding surfaces. Within the upper Limestone-Dolomite 'series' are a few diamictite beds ( $30 \mathrm{~cm}$ to $8 \mathrm{~m}$ thick). They appear to be of polygenetic origin, but are dominantly slump deposits. However, there are indications of ice-rafting in the form of possible dropstone structures. Further investigations are necessary to establish whether or not these beds do indeed represent the earliest glacial activity in the succession. These are similar to the beds in northern Suess Land. There is a rapid transitional contact with the overlying Lower Tillite which itself is largely of glacial origin.

Northern Syltoppene. The lower slopes of this mountain just outside the southern lateral moraine of Sorteelv Gletscher reveal a substantial, almost continuous section from carbonates at the top of the Limestone-Dolomite 'series' through the Lower Tillite, Inter-Tillite Beds and Upper Tillite, finishing near the coast with pure quartz sandstones whose stratigraphic position has not yet been established 
(fig. 33). The Lower Tillite which is predominantly yellow is brightly reddened in places, and contacts with associated lithologies, have been partially obscured by dolomitisation. The Lower Tillite (c. $265 \mathrm{~m})$ contains the largest boulders seen in the area (one dolostone measured $2.6 \times 1.9 \times 1.2 \mathrm{~m}$ ), but there are also finely laminated sediments with dropstones, as well as sandstone-wedges of periglacial origin. The Inter-Tillite Beds $(c .360 \mathrm{~m})$, though dominantly sandstone and dolomitic shale contain two diamictites in the middle. The Upper Tillite $(c .55 \mathrm{~m})$ dominated by sandstones and rhythmites is followed by crossbedded sandstones.

Kap Fletcher, Canning Land. A diamictite unit (from several metres to $50 \mathrm{~m}$ thick) is exposed in the seaward cliffs of this peninsula, but is disrupted by microgranite intrusions. It rests on dolostones of the Limestone-Dolomite 'series' and is overlain by sandstones. The diamictite is rather clast-poor, but the maroon appearance may indicate that it is the Upper Tillite (still to be verified). If so, much of the succession is missing, and the carbonates on which it rests are substantially brecciated. The brecciation could be the result of frost shattering and it may be that no Lower Tillite or Inter-Tillite Beds were ever deposited here.

\section{Facies analysis of Upper and Lower Tillites}

Facies analysis of diamictite and associated lithologies will ultimately provide a model of the complex depositional environment for much of the Vendian succession in East Greenland, and aid interpretation of the palaeogeography of the North Atlantic - Arctic region.

The 1984 season's work indicated that among the facies represented in the Upper and Lower Tillites were the following (with their provisional interpretation):

Massive diamictite, deposited as lodgement or meltout till, possible also as a result of mass flow.

Weakly bedded diamictite, deposited as waterlain till beneath a floating glacier tongue or as lodgement till in which shearing produced a pseudo-bedding structure.

Well bedded diamictite with dropstones, interpreted as marine sediments with a substantial iceberg-rafted component, distal from the glacier snout.

Rhythmites, deposited as turbidity underflows in a glacio-lacustrine environment. Icerafted debris sometimes present. Sometimes reminiscent of varves.

Lens-shaped sandstone and conglomerate bodies, representing proglacial braided river channel fillings.

Bedded sandstones, deposited in a marine or deltaic environment.

Shales, representing distal (glacio-) marine sediments.

Carbonates, deposited in shallow water by precipitation or more likely as glacial rock flour.

Sandstone wedges, the result of frost contraction in a subaerial periglacial environment.

Monomict breccia (rare), derived from supraglacial debris if associated with massive diamictite.

The precise genetic interpretation of diamictites has proved problematic here, as in other successions in the North Atlantic - Arctic region (Dowdeswell et al., in press). However, shape and fabric studies of diamictite stones, together with an assessment of bedding relations with adjacent units, and analysis of sedimentary structures, will provide a good indication of East Greenland palaeoenvironments in Vendian time. 
Acknowledgements. We acknowlege the assistance of the Geological Survey of Greenland especially N. Henriksen and A. K. Higgins. Financial support was provided by the University of Cambridge and the Cambridge Arctic Shelf Programme, pending the start of Grant GR3/5438 of the UK Natural Environment Research Council.

\section{References}

Dowdeswell, J. A., Hambrey, M. J. \& Wu, R. T. in press: A comparison of clast fabric and shape in Late Precambrian and modern glacial sediments. J. sedim. Petrol.

Hambrey, M. J. 1983: Correlation of Late Proterozoic tillites in the North Atlantic region and Europe. Geol. Mag. 120, 209-232.

Harland, W. B. 1964: Critical evidence for a great Infra-Cambrian glaciation. Geol. Rdsch. 54, 45-61.

Henriksen, N. 1981: The Charcot Land Tillite, Scoresby Sund, East Greenland. In Hambrey, M. J. \& Harland, W. B. (edit.) Earth's pre-Pleistocene glacial record, 776-777. Cambridge: Univ. Press.

Henriksen, N. \& Higgins, A. K. 1976: East Greenland Caledonian fold belt. In Escher, A. \& Watt, W. S. (edit.) Geology of Greenland, 182-246. Copenhagen: Geol. Surv. Greenland.

Higgins, A. K. 1981: The Late Precambrian Tillite Group of the King Oscars Fjord and Kejser Franz Josefs Fjord region of East Greenland. In Hambrey, M. J. \& Harland, W. B. (edit.) Earth's pre-Pleistocene glacial record, 778-781. Cambridge: Univ. Press.

Phillips, W. E. A. \& Friderichsen, J. D. 1981: The Late Precambrian Gåseland tillite, Scoresby Sund, East Greenland. In Hambrey, M. J. \& Harland, W. B. (edit.) Earth's pre-Pleistocene glacial record, 773-775. Cambridge: Univ. Press.

Spencer, A. M. in press: Mechanisms and environments of deposition of Late Precambrian geosynclinal tillites: Scotland and East Greenland. Palaeogeogr., Palaeoclimatol. \& Palaeoecol.

Vidal, G., 1979a: Acritarchs from the Upper Proterozoic and Lower Cambrian of East Greenland. Bull. Grønlands geol. Unders. 134, 40 pp.

Department of Earth Sciences, University of Cambridge, Downing Street, Cambridge CB2 $3 E Q$, 